\title{
The Effectiveness for Regional Budget of Revenue and Expenditure as a Control Tools in Enrekang Regency Governments
}

Fatmawati A. Rahman ${ }^{1}$, Romansyah Sahabuddin ${ }^{2}$, Abdul Karim ${ }^{3 *}$

${ }^{1}$ STIE Tridharma Nusantara, Makassar, South Sulawesi, Indonesia

${ }^{2}$ Universitas Negeri Makassar, South Sulawesi, Indonesia

${ }^{3}$ STIE AMKOP Makassar, South Sulawesi, Indonesia

DOI: $10.36348 /$ sjef.2021.v05i04.006

| Received: 21.02.2021 | Accepted: 12.04.2021 | Published: 18.04.2021

*Corresponding author: Abdul Karim

\section{Abstract}

The implementation of regional development in order to be carried out as expected, one of the influencing factors is the preparation of a financial budget in financing any regional development because without adequate financial budgeting, both in the form of revenue targets and realization of regional expenditures, financial management in the form of revenue and regional financial expenditures will not be implemented effectively. There are many efforts that can be made by local governments in improving people's welfare, one of which is the equitable distribution of development in a more just and balanced manner in each region. After conducting the research, the authors obtained the research results that in 2017 , $73.20 \%$ was categorized as less effective, in $201850.95 \%$ was categorized as ineffective, and in $201954.26 \%$ was categorized as ineffective. These three years show that the financial performance of the Enrekang Regency Government has decreased, for the efficient value in 2017 of $11.51 \%$, in 2018 it was $18.88 \%$, and in 2019 it was $19.44 \%$. During these three years, it shows that the regional financial performance is in the very efficient category.

Keywords: Effectiveness, Budget, Regional Income.

Copyright () 2021 The Author(s): This is an open-access article distributed under the terms of the Creative Commons Attribution 4.0 International License (CC BY-NC 4.0) which permits unrestricted use, distribution, and reproduction in any medium for non-commercial use provided the original author and source are credited.

\section{INTRODUCTION}

The regional revenue and expenditure budget at this event displays the financial plans obtained and used by the regional government in the framework of carrying out its duties for the implementation of the general budget in one fiscal year [1]. In accordance with the performance approach used in preparing the regional revenue and expenditure budget, each planned cost plan must be managed with the level of service or results expected to be achieved. The performance of local governments can assess the implementation of the regional revenue and expenditure budget.

Regional revenue and expenditure is an instrument that will ensure the creation of discipline in decision-making methods linked to regional income and expenditure policies [2]. In the framework of budgeting, the preparation of a budget, both revenue and as a basis for it is a government regulation, a ministerial decree, a regional regulation, or a regional head decree. So that the process of ordering the regional budget revenue and expenditure of the local government must follow the prescribed administrative method.
The technique of preparing the regional revenue and expenditure budget for readers aims to harmonize economic policies and available resources, allocate appropriate resources according to government policies, and prepare conditions for good budget management [3]. Therefore, budgeting is important in order for it to function as desired, namely regulations that are regulated by policy, budgets that provide direction for economic policies, and policies that state the resources owned by the community. The main function of the budget is to achieve macroeconomic balance in the economy, and the budget becomes a controlling tool to reduce imbalances and crises in various matters of the country. For this reason, concrete steps are needed in the form of improvement, refinement, accountability, and budget supervision [4]. To achieve limited budgetary authority, the maximum depends on government policy, so that the budget can be managed so that it is right on target or as expected.

In connection with the description above, in managing the regional revenue and expenditure budget, the Enrekang Regency government may experience or encounter where the effectiveness and efficiency of the 
Fatmawati A. Rahman et al., Saudi J Econ Fin, Apr, 2021; 5(4): 173-179

budget have not been achieved as expected [5]. So that researchers, the government of Enrekang Regency in carrying out the main tasks that are efficient, it is necessary to exercise the authority of the regional revenue and expenditure budget as a means of controlling the Enrekang Regency government, in order to optimize the performance of each agency and work unit.

\section{LITERATURE REVIEW Effectiveness}

Effectiveness is a condition that shows the extent to which the plan can be achieved. The more plans that can be achieved, the more effective these activities are so that the word effectiveness can also be interpreted as the level of success that can be achieved from a certain method or effort in accordance with the targets to be achieved [6].

Efficiency is a criterion of effectiveness refers to a measure of the use of resources that are rarely used by an organization. Efficiency is a comparison between output and input. The measure of efficiency consists of profit and capital, budget per segment, waste, time spent, budget per head, and so on [7]. Efficiency is measured based on the ratio between profit and the budget or time spent.

Efficiency is the relationship between goods and services (output) produced by activity or activity with the resources (input) used [8]. Efficiency is the input components that are used, such as time, energy, and costs that can be calculated and are not found in meaningless waste or expenditure.

Efficiency is defined as the ratio between output (output) and input (input), or the amount that results from one input used [9]. A company can be said to be efficient if it uses a smaller number of units when compared to the number of input units used by other companies to produce the same output or uses the same input unit, it can produce a larger number of outputs.

\section{Budget}

In exercising the rights and obligations as well as responsibilities that are accountable to the people, the government must have an intensive plan to achieve an expected target [10]. These plans are formulated intensively which will later be used as guidelines in every realization of the State's tasks. In essence, the important task of the government is in the management of State finances which covers all areas which are essentially the rights and obligations of the government. Therefore, a government plan to carry out State finances needs to be made and the plan is included in the form of a budget [11].

The budget is an important section of the government control system formed by the legislature in achieving the targets of government organizations [12].
The budget is not just a fixed number that will be implemented in the next period but is a representation of the commitment of each legislative party to work to realize short-term plans in order to achieve long-term goals [13].

The government budget is an official document resulting from an agreement between the executive and the legislature regarding expenditures determined to carry out government activities and the revenue expected to cover these expenditure needs or the financing required if a deficit or surplus is expected [14]. In general, there are 6 types of budget classifications, namely (1) organic classification, (2) object classification, (3) functional classification, (4) economic classification, (5) performance classification, and (6) program classification.

\section{Regional income}

In regional financial management, the revenue budget is that all regional revenues in the budget period concerned belong to the regional government and acquire regional assets [15]. It is explained in the Government Regulation of the Republic of Indonesia Number 58 of 2005, that regional revenue is the right of the regional government which is recognized as an addition to net worth [16]. Based on the government regulation of the Republic of Indonesia Number 58 of 2005 article 21, regional revenue as meant consists of 1) local revenue, 2) balancing funds and 3) other legitimate regional income [17].

Regional revenue as referred to in paragraph (1) letter a) includes all cash receipts through the regional general treasury account, which adds to the equity of the cancer fund, which is a regional right in one fiscal year that does not need to be paid by the region [18]. Regional expenditure as referred to in paragraph (1) letter b) includes all expenditures from the regional general treasury account which reduce the equity of cancer funds, which are regional obligations in one fiscal year for which the region will not be repaid [19]. Regional financing as referred to in paragraph (1) letter c) includes all revenues that need to be paid back and expenditures that will be received back, both in the relevant fiscal year and in the following fiscal years [20].

\section{METHOD RESEARCH}

The research instrument or tool used to assist this research is a questionnaire. A questionnaire is a list of questions or statements that are given and distributed to respondents or employees in a number of samples that are determined to be answered according to questions or statements about what they felt during their employment. In this technique, the researcher conducts a survey by distributing questionnaires that must be answered by the employees who are sampled. 
Fatmawati A. Rahman et al., Saudi J Econ Fin, Apr, 2021; 5(4): 173-179

The analytical method used in this research is the descriptive analysis method, which is a study conducted by collecting, managing, and then presenting data between 2017 - 2019 with the aim of knowing the effectiveness of the regional revenue and expenditure budget as a control tool for the Enrekang regency government. The ratios that can be developed based on financial data sourced from the efficiency of the regional revenue and expenditure budget include the effectiveness ratio.

The analytical method used in this research is the descriptive analysis method, which is a study conducted by collecting, managing, and then presenting data between 2017-2019 with the aim of knowing the effectiveness of the regional revenue and expenditure budget as a control tool for the Enrekang Regency government. The ratios that can be developed based on financial data sourced from the regional revenue and expenditure budget include the effectiveness ratio.

The effectiveness ratio describes the ability of the regional government to realize the planned local revenue, compared to the target set based on the real potential of the region. The greater the realization of the original regional revenue in the revenue target of the region's own revenue, the more effective it can be said, and vice versa. The effectiveness ratio is measured by:

$$
\text { Effectiveness ratio }=100 \% \frac{\text { Realized local revenue }}{\text { Target acceptance }}
$$

\section{RESULT AND DISCUSSION \\ Result \\ Regional revenue and expenditure budget}

Regional income and expenditure budgets, namely the annual financial plans of regional governments in Indonesia that are approved by the regional people's representative council. The regional income and expenditure budget is stipulated by regional regulations. The year for determining the regional income and expenditure budget covers a period of one year, starting from January 1 to December 31.

The revenue budget consists of (1) Regional original revenue, which includes local retribution, regional taxes, the results of the management of regional assets, and other revenues. (2) Part of the weighing fund, which includes profit-sharing funds, and general allocation and special allocation funds. (3) Other legitimate income such as grants or emergency funds.

Regional expenditures are all regional obligations that are recognized as a measure of the value of net assets in the period of the fiscal year concerned. Based on the decree of the Minister of Home Affairs of the Republic of Indonesia Number 29 of 2002, expenditure consists of (1) expenditure for regional apparatus, (2) expenditure for public services, (3) expenditure for profit sharing and financial assistance, and (4) unexpected expenditure.

\section{Report on the realization of the regional revenue and expenditure budget}

The regional income and expenditure budget is an annual financial plan that is established based on regional regulations. Regional Revenue Includes all cash receipts through the regional general cash account, which adds to the equity funds that are the right of the region in one fiscal year that does not need to be paid back by the region. Regional expenditures include all expenditures from the regional general treasury accounts which reduce the equity of funds in the fiscal year period for which the government will not be repaid.

To measure the effectiveness of the regional income and expenditure budget of Enrekang Regency, the following is a report on the realization of the regional income and expenditure budget from 2017 2019 as in the following table:

Table-1: Regional revenue and expenditure budget realization report Enrekang Regency in 2017

\begin{tabular}{|c|c|c|c|c|}
\hline Number & Type of data & Budget (IDR) & $\begin{array}{l}\text { Realization } \\
\text { (IDR) }\end{array}$ & Persentage \\
\hline \multirow[t]{6}{*}{1} & \multicolumn{4}{|l|}{ Income } \\
\hline & Locally-generated revenue & $129,615,126,887$ & 66,043,333,304 & $\mathbf{5 0 . 9 5}$ \\
\hline & Local tax revenue & $10,783,000,000$ & $10,843,118,014$ & 10.55 \\
\hline & Local retribution revenue & $33,757,347,000$ & $27,673,430,556$ & 81.98 \\
\hline & $\begin{array}{l}\text { Legalized revenue from the management of regional } \\
\text { assets }\end{array}$ & $15,100,000,000$ & $13,596,908,237$ & 90.05 \\
\hline & Legitimate local other income & $69,794,779,867$ & $13,929,876,497$ & 19.91 \\
\hline \multirow[t]{7}{*}{2} & \multicolumn{4}{|l|}{ Operational expenditure } \\
\hline & Total operating expenditures & $717,941,985,575$ & $680,870,609,277$ & 96.23 \\
\hline & Personnel spending & $399,458,279,431$ & $398,111,283,801$ & 99.66 \\
\hline & Shopping for goods & $263,226,426,499$ & $245,110,184,357$ & 93.12 \\
\hline & Subsidy & 0,00 & 0,00 & 0.00 \\
\hline & Grant & $54,757,279,645$ & $47,527,041,119$ & 86.80 \\
\hline & Social assistance & $500,000,000$ & $120,000,000$ & 24.00 \\
\hline
\end{tabular}


Fatmawati A. Rahman et al., Saudi J Econ Fin, Apr, 2021; 5(4): 173-179

\begin{tabular}{|c|c|c|c|c|}
\hline Number & Type of data & Budget (IDR) & $\begin{array}{l}\text { Realization } \\
\text { (IDR) }\end{array}$ & Persentage \\
\hline 3 & \multicolumn{4}{|l|}{ Receipt of financing } \\
\hline & Total financing receipts & 49,322,557,981 & $6,342,232.796$ & 12.86 \\
\hline & Use of excess budget financing & $6,222,557,981$ & $6,221,468,702$ & 99,98 \\
\hline & Domestic loans of bank financial institutions & $43,000,000$ & 0,00 & 0.00 \\
\hline & Domestic loans - others & 0,00 & $106,199,818$ & 0.00 \\
\hline & Acceptance of term installment loan & $100,000,000$ & $14,564,274$ & 14,56 \\
\hline \multirow[t]{4}{*}{4} & \multicolumn{4}{|l|}{ Financing expenditures } \\
\hline & Total expenses & $12,400,000,000$ & $12,000,000,000$ & 96.77 \\
\hline & Equity participation / local government investment & $12,000,000,000$ & $12,000,000,000$ & 100.00 \\
\hline & Lending to other governments & $400,000,000$ & 0,00 & 0.00 \\
\hline 5 & \multicolumn{4}{|l|}{ Remaining budget financing } \\
\hline & Remaining budget financing & 0,00 & $5,217,643,726$ & 0.00 \\
\hline
\end{tabular}

Source: Regional financial and expenditure agency of Enrekang Regency, 2020.

The regional income and expenditure budget of Enrekang Regency comes from the state revenue and expenditure budget, the regional income and expenditure budget of South Sulawesi Province, and the Regency regional income and expenditure budget, in 2017, the total regional income planning is IDR 136,152,091,582 with the realization of IDR 99,669,276,952.37 (73.20\%), total regional expenditure amounting to IDR 707,508,330,458 with the realization of IDR $667,326,043,707$ (94.32\%), total financing income of IDR 49,322,557,981 with the realization of IDR $6,342,232,795.17(12.86 \%)$. Total financing expenditures amounted to IDR $12,400,000,000$ with the total realization of IDR $12,000,000,000(96.77 \%)$. The remainder of the calculation of budget financing for the year relating to the realization amounted to IDR 7,150,734,737.54.

Table-2: Regional revenue and expenditure budget realization report Enrekang Regency in 2018

\begin{tabular}{|c|c|c|c|c|}
\hline Number & Type of data & Budget (IDR) & $\begin{array}{l}\text { Realization } \\
\text { (IDR) }\end{array}$ & Persentage \\
\hline \multirow[t]{6}{*}{1} & \multicolumn{4}{|l|}{ Income } \\
\hline & Locally-generated revenue & $\mathbf{1 3 6 , 1 5 2 , 0 9 1 , 5 8 2}$ & $99,669,276952.37$ & 73.20 \\
\hline & Local tax revenue & $9,965,000,000$ & $9,023,051,580$ & 90.55 \\
\hline & Local retribution revenue & $30,165,130,944$ & $26,044,548,348$ & 86.34 \\
\hline & $\begin{array}{l}\text { Legalized revenue from the management of } \\
\text { regional assets }\end{array}$ & $12,600,000,000$ & $12,355,808,162$ & 98.06 \\
\hline & Legitimate local other income & $83,421,960,638$ & $52,245,868,861$ & 62.63 \\
\hline \multirow[t]{7}{*}{2} & \multicolumn{4}{|l|}{ Operational expenditure } \\
\hline & Total operating expenditures & $707,508,330,458$ & $667,326,043,707$ & 94.32 \\
\hline & Personnel spending & $391,499,847,204$ & $369,600,973,631$ & 94.41 \\
\hline & Shopping for goods & $276,627,152,938$ & $265,801,742,751$ & 96.09 \\
\hline & Subsidy & $928,656,000$ & 0,00 & 0.00 \\
\hline & Grant & $37,707,674,316$ & $31,716,827,325$ & 86.11 \\
\hline & Social assistance & $745,000,000$ & $206,500,000$ & 27.72 \\
\hline \multirow[t]{4}{*}{3} & \multicolumn{4}{|l|}{ Receipt of financing } \\
\hline & Total financing receipts & $7,250,734,737$ & $7,164,527,237$ & 98.81 \\
\hline & Use of remaining budget financing & $7,150,734,737$ & $7,150,734,737$ & 100.0 \\
\hline & Acceptance of Term Installment Loan & $100,000,000$ & $13,792,500$ & 13.79 \\
\hline \multirow[t]{4}{*}{4} & \multicolumn{4}{|l|}{ Financing expenditures } \\
\hline & Total expenses & $9,890,000,000$ & $9,490,000,000$ & 95.96 \\
\hline & $\begin{array}{l}\text { Equity participation / local government } \\
\text { investment }\end{array}$ & $9,490,000,000$ & $9,490,000,000$ & 100.0 \\
\hline & Lending to other governments & $400,000,000$ & 0,00 & $\mathbf{0 . 0 0}$ \\
\hline \multirow[t]{2}{*}{5} & \multicolumn{4}{|l|}{ Remaining budget financing } \\
\hline & Remaining budget financing & 0,00 & $5,217,643,726$ & 0.00 \\
\hline
\end{tabular}

Source: Regional financial and expenditure agency of Enrekang Regency, 2020.

The regional income and expenditure budget of Enrekang Regency comes from the state revenue and expenditure budget, the regional income and expenditure budget of South Sulawesi Province, and the Regency regional income and expenditure budget, in 2018, the total regional income planning is IDR 
Fatmawati A. Rahman et al., Saudi J Econ Fin, Apr, 2021; 5(4): 173-179

$129,615,126,887$ with the realization of IDR $66,043,333,304.23(50,95 \%)$, total regional expenditure was IDR $717,941,985,575$ with the realization of IDR $680,870,509,277(96.23 \%)$, total financing income was IDR 7,250,734,737 with the realization of IDR
$7,164,527,237.54 \quad(98.81 \%)$. The total financing expenditure was IDR $9,890,000,000$ with the total realization of IDR 9,490,000,000 (95.96\%). The remainder of the calculation of budget financing for the year relating to the realization is IDR 5,217,643,726.99.

Table-3: Regional revenue and expenditure budget realization report Enrekang Regency in 2019

\begin{tabular}{|c|c|c|c|c|}
\hline Number & Type of data & Budget (IDR) & $\begin{array}{l}\text { Realization } \\
\text { (IDR) }\end{array}$ & Persentage \\
\hline \multirow[t]{6}{*}{1} & \multicolumn{4}{|l|}{ Income } \\
\hline & Locally-generated revenue & $134,973,760,140$ & $73,239,444,538$ & 54.26 \\
\hline & Local tax revenue & $12,247,173,134$ & $10,523,206,720$ & 85.92 \\
\hline & Local retribution revenue & $39,754,361,000$ & $30,097,583,858$ & 75.71 \\
\hline & $\begin{array}{l}\text { Legalized revenue from the management of } \\
\text { regional assets }\end{array}$ & $16,741,119,760$ & $16,741,119,760$ & 100.0 \\
\hline & Legitimate local other income & $66,231,106,246$ & $15,877,534,200$ & 23.97 \\
\hline \multirow[t]{7}{*}{2} & \multicolumn{4}{|l|}{ Operational expenditure } \\
\hline & Total operating expenditures & $760,417,874,923$ & $713,251,271,965$ & 93.80 \\
\hline & Personnel spending & $412,893,876,391$ & $405,311,534,344$ & 98.16 \\
\hline & Shopping for goods & $299,792,665,391$ & $279,728,138,631$ & 93.31 \\
\hline & Subsidy & 0,00 & 0,00 & 0.00 \\
\hline & Grant & $47,034,733,059$ & $27,690,602,990$ & 58.87 \\
\hline & Social assistance & $696,500,000$ & $521,000,000$ & 74.80 \\
\hline \multirow[t]{4}{*}{3} & \multicolumn{4}{|l|}{ Receipt of financing } \\
\hline & Total financing receipts & $8,412,389,871$ & $\mathbf{5 , 2 2 1 , 9 7 8 , 7 2 6}$ & 62.07 \\
\hline & Use of excess budget financing & $5,217,643,727$ & $5,217,643,726$ & 100.0 \\
\hline & Acceptance of term installment loan & $3,194,746,144$ & $4,335,000$ & 0.14 \\
\hline \multirow[t]{4}{*}{4} & \multicolumn{4}{|l|}{ Financing expenditures } \\
\hline & Total expenses & $2,500,000,000$ & $2,100,000,000$ & 84.00 \\
\hline & $\begin{array}{l}\text { Equity participation / local government } \\
\text { investment }\end{array}$ & $2,100,000,000$ & $2,100,000,000$ & 100.00 \\
\hline & Lending to other governments & $400,000,000$ & 0,00 & 0.00 \\
\hline \multirow[t]{2}{*}{5} & \multicolumn{4}{|l|}{ Remaining budget financing } \\
\hline & Remaining budget financing & 0,00 & $17,142,104,238$ & 0.00 \\
\hline
\end{tabular}

Source: Regional financial and expenditure agency of Enrekang Regency, 2020.

The regional income and expenditure budget of Enrekang Regency comes from the state revenue and expenditure budget, the regional income and expenditure budget of South Sulawesi Province, and the Regency regional income and expenditure budget, in 2019. The total regional revenue planning is IDR $134,973,760,140$ with realization of IDR $73,239,444,538.3526 \%$ ), total regional expenditure amounting to IDR $760,417,874,923$ with realization of IDR $713,251,271,965.42(93.80 \%)$, total financing receipts of IDR. 8,412,389,871 with a realization of IDR 5,221,978,726.99 (62.07\%), total financing expenditure of IDR 2,500,000,000 with a total realization of IDR $2,100,000,000(84.00 \%)$. And the remainder of the calculation of budget financing for the year with respect to the realization of IDR $17,142,104,238.15$.

\section{DISCUSSION}

The regional revenue and expenditure budget requires a good plan and realization in order to improve the function of the relevant government services. In addition, the regional revenue and expenditure budget can also reflect the value of effectiveness and efficiency value. The effectiveness value describes the ability of the local government to realize the planned local revenue compared to the target set based on the real potential of the region. The higher the effectiveness value, the better the regional capability.

The efficiency value illustrates the comparison between the numbers of costs incurred to collect original regional income with the realization of the original regional income received. The smaller the efficiency value, the better the government's performance. For this reason, local governments need to carefully calculate how much they spend to realize all the original revenue received so that it can be seen whether the collection of revenue from the region is efficient or not.

Based on the explanation above, the effectiveness and efficiency of the regional revenue and expenditure budget and financial development and performance of the Enrekang district government which is based on the results of the calculation of the 
Fatmawati A. Rahman et al., Saudi J Econ Fin, Apr, 2021; 5(4): 173-179

effectiveness and efficiency ratio analysis is the effectiveness of the budget and regional expenditure revenue of the Enrekang Regency government in 2017 of $73.20 \%$ categorized as lacking. Effective, in 2018 $50.95 \%$ was categorized as ineffective, and in 2019 $54.26 \%$ was categorized as ineffective. These three years have shown that the financial performance of the Enrekang Regency Government has decreased; this is because the regional income has decreased so that the total regional income does not reach the target.

The regional revenue and expenditure budget plays a very important role and function in running the government in Enrekang Regency. The regional income and expenditure budget functions as a means of controlling the running of the government. The Enrekang Regency government views that the regional budget, revenue, and expenditure that is compiled and stipulated by regional regulations every year is a tool to answer the continuity of the dynamics of the sustainability of regional and community development, thus the Enrekang Regency government always makes every effort to harmonize the regional revenue and expenditure budget. The preparation of regional revenue and expenditure budgets requires transparency and accountability, effectiveness, and efficiency to facilitate control of development and governance so that government performance can be measured through evaluation of regional revenue and expenditure budget reports.

\section{CONCLUSION}

Based on the comparison of the analysis of the effectiveness ratio to the regional revenue and expenditure budget of Enrekang Regency between 2017-2019, in general, it can be concluded that: (1) The effectiveness and efficiency value of the local government is less able to realize local revenue. Local revenue targets are set based on real potential as well as cost savings made by local governments in realizing local government plans and programs. (2) The regional revenue and expenditure budget of Enrekang Regency in 2017 is categorized as ineffective, 2018 is categorized as ineffective, and 2019 is categorized as ineffective. (3) The management of the regional revenue and expenditure budget is able to guarantee the success of the implementation of development or the economy in improving the function of community services in Enrekang Regency.

\section{REFERENCES}

1. Karim, A., Musa, C. I., \& Romansyah Sahabuddin, M. A. (2021). The Increase of Rural Economy at Baraka Sub-District through Village Funds. Journal The Winners, 22(1).

2. Lindawati, A. S. L., \& Puspita, M. E. (2015). Corporate Social Responsibility: Implikasi Stakeholder dan Legitimacy Gap dalam Peningkatan Kinerja Perusahaan. Jurnal Akuntansi
Multiparadigma, $6(1), \quad 157-174$. doi:10.18202/jamal.2015.04.6013.

3. Maddatuang, B., Sabara, Z., Wekke, I. S., \& Karim, A. (2020). Langkah Mewujudkan Insan Cita Pandangan Lintas Disiplin. Penerbit Qiara Media.

4. Maddatuang, B., Syukur, A., Indar, S. H., \& Karim, A. (2021). THE RURAL ECONOMIC GROWTH IN SOUTH SULAWESI DRIVES THE NATIONAL SUSTAINABLE DEVELOPMENT GOALS. International Journal of Management (IJM), 12(3).

5. Manossoh, H. (2015). Implementasi sistem akuntansi pemerintahan dalam mewujudkan good government governance pada Pemerintah Provinsi Sulawesi Utara. Jurnal Berkala Ilmiah Efisiensi, 15(5).

6. Musa, C. I., \& Hasan, M. (2018). The influence of social, economic, and demographic characteristic on working hours of micro, small, and medium enterprises (MSMEs) in Makassar City. In J. Phys.: Conf. Ser (Vol. 1028, p. 012181).

7. Musa, C. I., Parinsi, W. K., \& Rasyid, R. (2019). Penguatan Ekonomi Kreatif Berbasis Potensi Sumber Daya Desa pada Masyarakat Desa Kaliang Kecamatan Duampanua Kabupaten Pinrang. In Seminar Nasional Pengabdian Kepada Masyarakat (Vol. 2019, No. 2).

8. Musa, C. I., Rami, A., \& Hasan, M. (2019). How does the family capital and market orientation affect the business performance of the family business in the manufacturing sector? In First International Conference on Materials Engineering and Management-Management Section (ICMEMm 2018). Atlantis Press.

9. Nur, M., \& Rosmawati, A. K. (2020). Effect of Attendance, Compensation, and Satisfaction Againts Effectivity of Ferformance Employee at Regent Enrekang Office. International Journal of Scientific \& Engineering Research,11(10), 129132.

10. Rabiyah, U., Suryani, A., \& Karim, A. (2021). The Effect of Awareness, Fiscus Services and Taxation Knowledge on Taxpayer Compliance At Madya Makassar Kpp. International Journal of Innovation Scientific Research and Review, 3(1), 797-799.

11. Safitri, D. (2017). Faktor faktor yang mempengaruhi penerapan standar akuntansi pemerintahan berbasis akrual (Studi pada skpd pemerintah kabupaten Bengkalis). Jurnal Akuntansi (Media Riset Akuntansi \& Keuangan), 5(2), 174-189.

12. Sahabuddin, R. (2013). Analisis Efikasi Diri dan Komitmen Berwirausaha Serta Dampaknya Pada Kinerja Usaha Rumput Laut Skala Kecil di Kabupaten Jeneponto. Economix, 1(1).

13. Sahabuddin, R. (2014). The Entrepreneurship Characteristics in Relation to Improve the Performance of the Small-Scale Seaweed Entrepreneurs. 
Fatmawati A. Rahman et al., Saudi J Econ Fin, Apr, 2021; 5(4): 173-179

14. Sahabuddin, R. (2016). Development of business values and behaviours: Takalar district, South Sulawesi (Indonesia) case study. Актуальні проблеми економіки, (2), 440-449.

15. Sahabuddin, R. (2018). Effect of entrepreneurship commitment to self-efficacy through intention of entrepreneurship and competence. International Journal of Business and Management Science, 8(1), 67-81.

16. Sahabuddin, R. (2019). Pengaruh Role Overload Terhadap Kinerja Pegawai Pada Kantor Badan Kepegawaian dan Diklat Daerah Kabupaten Mamuju Tengah (Studi Kasus Seleksi Berkas CPNS Kabupaten Maтuju Tengah Tahun 2014). Economix, 4(1).

17. Sanjaya, A., Rasuli, M., \& Haryani, E. (2017). Pengaruh Penerapan Standar Akuntansi Pemerintahan, Sistem Pengendalian Intern, Sistem Akuntansi Keuangan Daerah, Dan Sumber Daya Manusia Terhadap Kualitas Laporan Keuangan
Pemerintah Daerah Dengan Komitmen Organisasi Sebagai Pemoderasi (Studi Pada Skpd $K a$ (Doctoral dissertation, Riau University).

18. Sudiarianti, N. M., Ulupui, I. G. K. A., \& Budiasih, I. G. A. (2015). Pengaruh Kompetensi Sumber Daya Manusia Pada Penerapan Sistem Pengendalian Intern Pemerintah dan Standar Akuntansi Pemerintah Serta Implikasinya Pada Kualitas Laporan Keuangan Daerah. Simposium Nasional Akuntansi XVIII.

19. Syukur, A., Novianti, A. S., \& Karim, (2021). Financial Ratio Analysis of Pt. Semen Tonasa before and After Joining the Semen Indonesia Group.

20. Zeyn, E. (2011). Pengaruh good governance dan standar akuntansi pemerintahan terhadap akuntabilitas keuangan dengan komitmen organisasi sebagai pemoderasi. Jurnal Reviu Akuntansi dan Keuangan, 1(1), 21-36. 